\title{
Feeding ecology of the South American sea lion Otaria flavescens: food contents and food selectivity
}

\author{
Mario George-Nascimento*, Rodrigo Bustamante and Ciro Oyarzun \\ Departamento Biología y Tecnología del mar, Pontificia Universidad Católica de Chile, Casilla 127, Talcahuano, Chile
}

\begin{abstract}
While predation by pinnipeds is likely to be important in shaping the structure of marine communities, there are few reports from the South Eastern Pacific Ocean where pinniped populations are abundant and a massive fishing industry has developed in recent years. We report the food contents of 29 South American sea lions Otaria flavescens Shaw, 1800 and quantitative information on the occurrence of prey taxa by frequency and mass. Estimates of the relative abundance of prey taxa in the environment, daily and annual food consumption rates, and sea lions food selectivity are given. Sea lions tend to consume slow swimming, bentho-demersal fish species, rather than the more abundant pelagic fish species in the study area. The jack mackerel Trachurus murphyi (Nichols) was the most frequent prey item found in the alimentary tracts and in the environment, but it was not preferred nor was it an important contributor of biomass to the diet. The non-commercial hake Macruronus magellanicus (Lönnberg) was the most preferred and the most important by mass in the diet. Estimated annual consumption of cusk eels (Genypterus spp.) revealed that sea lions took ca. 7 times more fish in mass than those annually landed in the study area. Unfortunately, estimates of standing stocks for the different prey taxa consumed by the sea lions are not yet available, and so the magnitude of their impact on fisheries is difficult to evaluate.
\end{abstract}

\section{INTRODUCTION}

Knowledge on the food habits of pinnipeds facilitates a better understanding of their interaction with prey populations. Quantitative information allows an approximate assessment of their impact upon commercially exploited fish species (Рarrish and Shearer, 1977; Fiscus, 1979, 1982) and that of fishery upon their feeding habits (Sergeant, 1973, 1976; FAO, 1978). Predation by pinnipeds is likely to be important in shaping the structure of marine communities (Estes, 1979); consequently, the role of pinnipeds should be considered when a multispecies approach to fisheries management is attempted (Anderson and Ursin, 1977; May et al., 1979; Majkowski, 1981; Bailey and Ainley, 1982).

Sea lions are opportunistic near-shore predators that occasionally enter estuaries and rivers (Schlatter, 1977;

\footnotetext{
- Present address: Departamento de Biología Ambiental, Pontificia Universidad Católica de Chile, Casilla 114-D, Santiago, Chile
}

FAO, 1978; Antonellis and Fiscus, 1980). The only known exception to this is the Australian sea lion Neophoca cinerea (Perón, 1816) which feeds relatively far offshore (FAO, 1979). The wide variety of food items that sea lions consume include mostly teleosts and cephalopods as their main prey, with gastropods, crustaceans, birds and algae as occasional food items (Boswall, 1972; Aguayo and Maturana, 1973; FAO, 1979).

The total population of the South American sea lion Otaria flavescens Shaw, 1800 has been estimated at 329,000 individuals (Sielfeld et al., 1977, 1978; Saavedra, 1980). Of this total, about 109,000 occur in the Eastern Pacific Ocean $(20,000$ in Peru and 89,000 in Chile). These numbers include about 58,000 individuals living between $41^{\circ} \mathrm{S}$ and $56^{\circ} \mathrm{S}$ that were not considered in FAO (1979). The bulk of the Eastern Pacific population lives in the vicinity of fishing areas, where fishermen claim that their numbers should be controlled because they damage nets and compete for the same resources. Fig. 1 shows the study area, the BíoBio Region in Central Chile, where about 12,000 individuals live (Sielfeld et al., 1977; SERPLAC, 1981; 


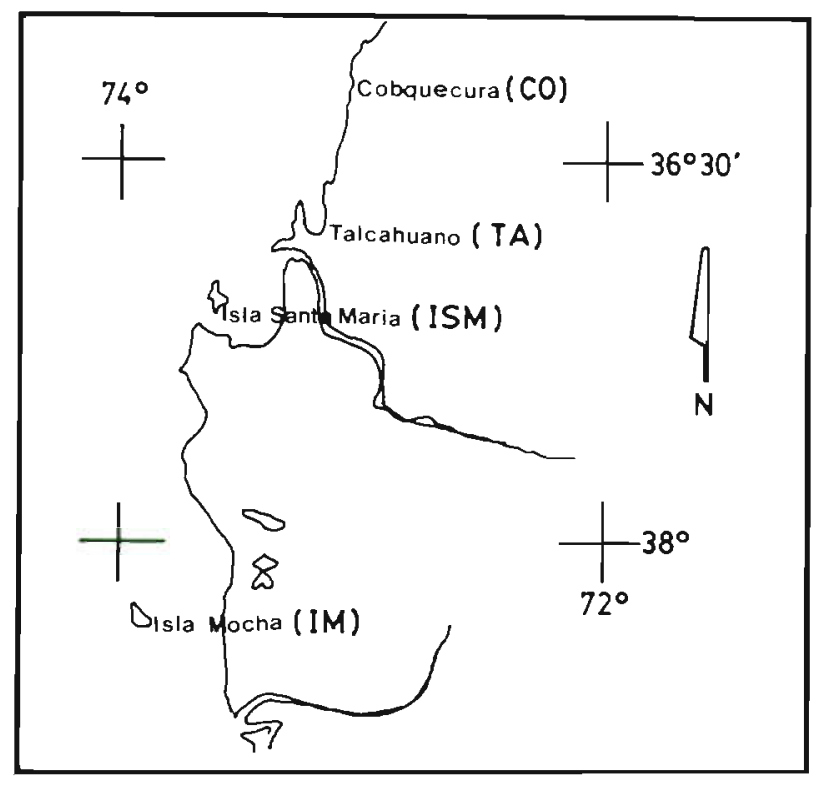

Fig. 1. Study area: Bío-Bío Region in Central Chile

unpubl. censuses based on photographic counts by M. G. -N.).

Previous reports on the feeding habits of the South American sea lion come mainly from populations inhabiting the Atlantic Ocean, where anchovies Engraulis anchovita, bottom fishes and squid are important in the diet (Hamilton, 1934; Carrara, 1952; Boswall, 1972; Vaz-Ferreira, 1979). In the Eastern Pacific Ocean, Aguayo and Maturana (1973) reported that in 16 out of 32 stomachs sampled in Valparaiso $\left(33^{\circ} \mathrm{S}\right)$, rockfish Sebastodes oculatus, hake Merluccius gayi, pilchard Clupea bentinckii, giant squid Dosidicus gigas, snails Tegula spp., loco Concholepas concholepas and nylon shrimp Heterocarpus reedi were the main prey taxa. Fish were present in $75 \%$ of stomachs with food remains, whereas molluscs and crustaceans were found in $35 \%$ of them. In a recent report (SERPLAC, 1981), 13 out of 47 stomachs sampled in Cabo Carranza ( $\left.35^{\circ} \mathrm{S}\right)$ contained the following food items: hake Merluccius gayi (in $69 \%$ of the stomachs with food remains), the chimaerid Callorhynchus callorhynchus $(38.5 \%)$, rockfish Sebastodes oculatus ( $8 \%$ ), pilchard Clupea bentinckii $(8 \%)$ and occasionally the spider crab Taliepus dentatus. In both of these studies, most of the sea lions sampled were bulls and pups, caught at the end of the breeding season (summer), which probably accounted for the high number of empty stomachs. However, both of the reports only mention the proportion of stomachs where a given prey taxon was found (Aguayo and Maturana, 1973; SERPLAC, 1981).

Here we report the food contents found in 29 South American sea lions caught mainly during spring 1980 and 1981. We obtained quantitative information on the incidence and the numerical and weight contribution of each prey taxon to the diet, as well as estimates of the relative abundance of prey taxa in the environment. With these data we analyzed the sea lions' food selectivity and estimated their daily and annual foodconsumption rates.

\section{MATERIAL AND METHODS}

Between August 1979 and November 1981, 29 South American sea lions, from 4 sites in Central Chile, were killed using a rifle. Each individual was dissected at a nearby beach, after recording its body length $(\mathrm{cm})$ and sex. Body weight $(\mathrm{kg})$ was estimated using SERPLAC (1981) data. Alimentary tracts were opened (from oesophagus up to the rectum), their contents preserved in $70 \%$ ethanol and stored at $-20^{\circ} \mathrm{C}$ for no more than 1 mo before examination in the laboratory. We collected all food remains, stones and parasite infrapopulations retained by a sieve with $1 \mathrm{~mm}$ mesh size.

Fish otoliths (sagittae) were preliminarily identified according to Hecht (1978) and Hecht and Hecht (1978), and later by comparison with a reference collection. For fish species with small otoliths (e.g. Trachurus murphyi and Sardinops sagax) identification of individuals was by retrieval of some characteristic skeletal bones (e.g. the supraoccipital bone in T. murphyi). Otoliths of the 3 cusk eel species in the study area (Genypterus chilensis, G. maculatus, G. blacodes) allowed identification only to genus because of their close similarity. The remaining otolith fragments represented $15 \%$ of total otolith biomass, and were identified only to the order level. However, these otoliths most likely belonged to Merluccius gayi or Macruronus magellanicus. Cephalopod beaks were identified by Juan Carlos Castilla (Pontificia Universidad Católica de Chile, Santiago) employing Clarke's (1962) key. The numbers of elasmobranchs were determined from the presence of claspers, skulls, ova or dermic denticles.

Total numbers of prey taxa and of prey individuals per alimentary tract were recorded. Total number of fish per alimentary tract was estimated as half the number of otoliths when they outnumbered skulls or vertebral columns in the sample. Upper and/or lower cephalopod beak counts provided estimates of their numbers per alimentary tract. In 1 adult male caught at Talcahuano, the number of prey individuals was not counted, but the different prey taxa present were recorded. Total weight of stones per stomach was also listed. Preliminary results on the magnitude of the parasitism have been published elsewhere (GeorgeNascimento and Carvajal, 1981). 
Table 1. Regression equations for relations between otolith (OL) length and fish length (FL), and fish length with fish weight (FW) for 2 prey taxa of the South American sea lion Otaria flavescens

\begin{tabular}{|c|c|}
\hline Macruronus magellanicus & Genypterus maculatus \\
\hline $\mathrm{FL} \mathrm{cm}=7.587+3.52 \mathrm{OL} \mathrm{mm}$ & $\mathrm{FL} \mathrm{cm}=-11.12+5.55 \mathrm{OL} \mathrm{mm}$ \\
\hline $\mathrm{FW}_{\mathrm{g}}=3.28 \times 10^{-3} \mathrm{FL}{ }^{2.954} \mathrm{~cm}$ & $\mathrm{FW}_{\mathrm{g}}=8.627 \times 10^{-6} \mathrm{FL}^{2890} \mathrm{~mm}$ \\
\hline $\begin{aligned} \text { Sources: } & \text { Aguayo (1971) } \\
& \text { IFOP (1979) }\end{aligned}$ & $\begin{array}{l}\text { Javier Chong, Universidad Católica de Chile, } \\
\text { Chile, Sede Talcahuano, (pers. comm.) }\end{array}$ \\
\hline
\end{tabular}

Table 1 gives the regression equations relating otolith length (measured to the nearest $0.1 \mathrm{~mm}$ ) to fish length, and fish length to fish weight. These were used for estimating prey size and weight in taxa whose otoliths were large, identifiable and complete. Although similar published equations are available for Merluccius gayi (Guichenot), we did not use them because differential growth rates have been reported for the 2 sexes (IFOP, 1979). For other prey taxa we used the modal size and weight at landing (IFOP, 1979), except for cephalopods whose approximate weight was provided by J. C. Castilla. The relation between the size of Macruronus magellanicus and that of the predator was assessed by the Spearman rank correlation coefficient $\left(r_{\mathrm{s}}\right)$.

The estimated amount of food in each sea lion, when expressed as percentage of the sea lion's body weight, was considered to be an estimator of the daily intake rate, because it has been reported that, in this species, food persists for ca. 12 to $18 \mathrm{~h}$ in the alimentary tract (Ximenez, 1976). Annual food consumption of the population in the study area was evaluated by multiplication of the estimated daily intake by the number of days in a year that a sea lion spends feeding, and by the sea lions' population size. We included the age class structure of populations in the study area and the mean weight of individuals per age class (SERPLAC, 1981). We assumed that adult males feed $330 \mathrm{~d}$ a year because they fast for 1 mo during the breeding season (Ximénez, 1976).

Because several alimentary tracts in the sample contained more than 1 prey taxon, we tested the assumption that sea lions capture each item of prey independently; that is, if each prey item represents a meal (Sergeant, 1973; Frost and Lowry, 1980; Pitcher, 1980). We used recurrent group analysis, corrected for sample size (Fager, 1957; Hayes, 1978) for prey taxa with more than 5 occurrences. In these same alimentary tracts we estimated a hierarchy of dominance for each prey taxon, as the ranking of the ratio between the number of alimentary tracts where a given prey taxon dominated in weight and/or number of prey individuals, over its total number of joint occurrences. In this latter case, we considered only the alimentary tracts that contained more than 10 prey individuals. These estimates of co-occurrence and dominance allow determination of whether each occurrence represents a meal, and how the amount of food ingested per feeding period is partitioned among prey taxa, respectively. A feeding period is considered to be the feeding activity of sea lions on a daily basis.

The numerical component of each prey taxon in the diet has been by far the most frequently neglected component in the calculation of the index of relative importance (IRI) because of its strong dependence on size disparity of prey taxa (Spalding, 1964; Pitcher, 1980). We included this component in the calculation of IRI because of its importance in those behavioral processes that involve the selection of prey individuals (e.g. preference for a particular prey taxon, parasite transmission, acquisition of vitamins or of trace elements). This index was based on ranks and has the advantage of not depending on the accuracy of individual counts or on assumptions of statistical normality (Lehmann, 1975). IRI was calculated as the ranking of

$$
\frac{\mathrm{R}_{\mathrm{w}_{1}}+\mathrm{R}_{\mathrm{n} 1}+\mathrm{R}_{\mathrm{ol}}}{3}
$$

where, $R_{w 1}=$ rank of the contribution in weight of the ith prey taxon to the diet; $\mathrm{R}_{n i}=$ rank of the contribution in number of prey individuals of the $i$ th prey taxon to the diet; $R_{o i}=$ rank of the contribution in number of occurrences over meals in the sample of the ith prey taxon to the diet.

Food selectivity was estimated using Johnson's (1980) method. Ranking of the availability of demersal fish species was based on data from 74 bottom trawls made in the study area by the R/V 'Itzumi' during September-November 1981, at depths less than $300 \mathrm{~m}$ (Henriquez, 1982). We also recorded the range of depths where fishes were caught, as well as those with maximum biomass. Availability of pelagic fish species was based on data from landing statistics in the study area (SERNAP, 1980, 1981). Although both pelagic and 
demersal cephalopod species were found in the alimentary tracts, we lumped them together for analysis.

\section{RESULTS}

Body length of the 29 sea lions sampled ranged between 1.10 and $2.46 \mathrm{~m}$ (mean $=1.89 \mathrm{~m}$; $\mathrm{SD}=0.44)$; their weight ranged between 50 and $310 \mathrm{~kg}$ (mean = $190 \mathrm{~kg}$; $\mathrm{SD}=8.24$ ). Twenty five of them had food remains in their alimentary tract; 23 had stones in their stomach whose mean weight was $0.8 \mathrm{~kg}(\mathrm{SD}=0.5)$. A total of 820 prey individuals was identified in 24 sea lions; 1,436 otoliths collected enabled us to identify 732 fishes, and skulls or single bone pieces enabled the identification of a further 83 fishes. The remaining 5 prey were cephalopods. A detailed account of the food contents found in the 29 sea lions in the sample is shown in Table 2.
Frequency distributions of the number of prey individuals and of the number of prey taxa per sea lion are shown in Fig. 2. Most $(n=20)$ of the sea lions sampled contained more than 1 prey taxon in their alimentary tract, but the number of prey taxa per sea lion was not correlated with predator's size $\left(r_{s}=0.27 ; N S\right)$. In those alimentary tracts with at least 2 prey taxa, the dominant one accounted for $79.8 \%(\mathrm{SD}=9.9$ ) of the total number of prey individuals, and for $71.2 \%(\mathrm{SD}=12.5)$ of the food weight per alimentary tract. However, not all prey taxa were dominant. Table 2 shows that Macruronus magellanicus frequently outnumbered and outweighed other co-occurrent prey taxa.

The high variance $\left(\right.$ mean $\left.=34.2 ; \mathrm{S}^{2}=1,953.6\right)$ of the number of prey individuals per sea lion can be explained in part by the great disparity in size of prey taxa. For example, one of the sea lions had more than 200 individuals of Macruronus magellanicus in its alimentary tract (mean fish body weight $=187 \mathrm{~g}$ ), with

Table 2. Body length, sex, collection date, locality of sampling and number of prey individuals per prey taxon found in each of the 29 sea lions in the sample. Dominance (number of stomachs where a prey dominated in weight and/or number/number of occurrences in stomachs with more than 1 prey taxon and more than 10 prey individuals) for 6 prey taxa

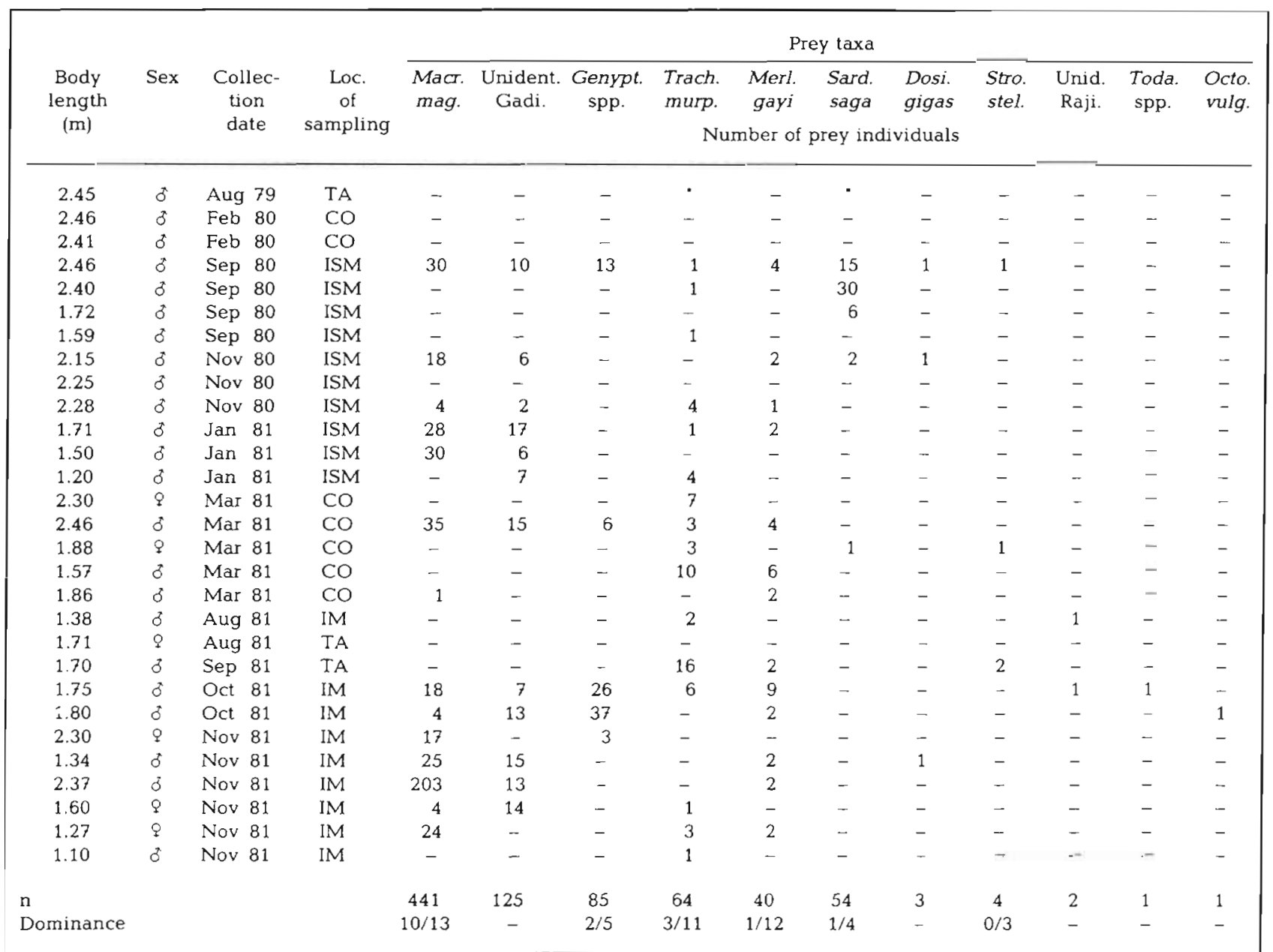




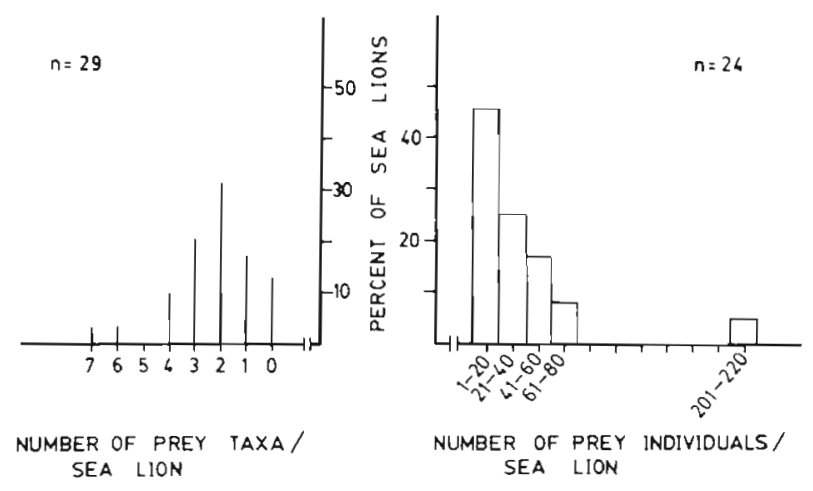

Fig. 2. Frequency distribution of the number of prey taxa per sea lion (left), and of the number of prey individuals per sea lion (right). Unidentified Gadiformes were considered a different prey taxon only if they did not co-occur with Macruronus magellanicus or Merluccius gayi

a food contents' weight similar to one that had 57 prey individuals of which the bulk (37) were Genypterus spp. (mean fish body weight $=916 \mathrm{~g}$ ). The number of prey individuals per sea lion was in part accounted for by the predator's size $\left(\mathrm{r}_{\mathrm{s}}=0.40 ; \mathrm{P}<0.05\right)$. Fig. 3 shows the size distribution of $M$. magellanicus in 12 sea lions, and its relation with predator size. No correlation was found between these 2 variables $\left(r_{s}=-0.06 ; \mathrm{NS}\right)$.

Table 3 lists the 11 prey taxa recognized in the alimentary tract of 25 sea lions. Although jack mackerel (Trachurus murphyi) had the highest number of occurrences, its numerical and weight contribution to the diet was rather low and its IRI was 2. Macruronus magellanicus was the prey with the highest IRI because of its top contribution to the considered components of the diet. Analysis of recurrent prey taxa revealed that not all pairs were randomly associated in the sea lions' alimentary tracts. $M$. magellanicus and Merluccius gayi tended to co-occur (Fager's affinity

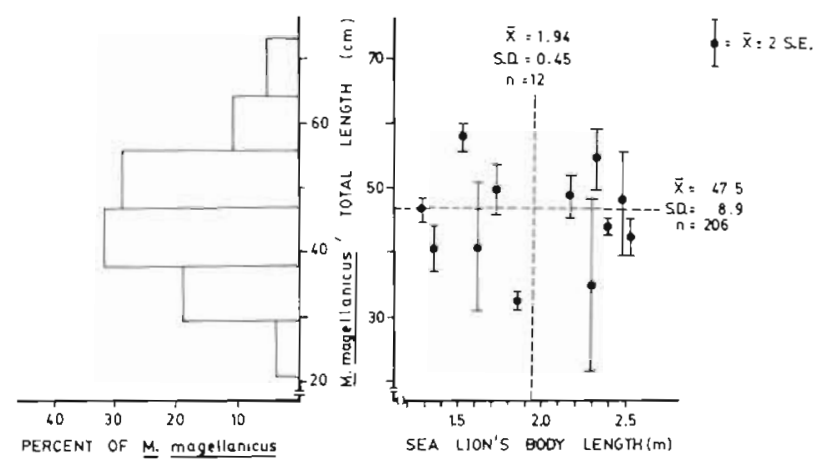

Fig. 3. Frequency distribution of total length of $206 \mathrm{MaC}-$ ruronus magellanicus found in sea lion stomachs (left), and its relation to sea lion body length (right)

index; $a=0.61 ; \mathrm{P}<0.04)$, but this was not the case with Genypterus spp./Sardinops sagax, T. murphyi/M. magellanicus, and $T$. murphyi/M. gayi.

Table 4 shows the ranking of availabilities, habitat, vertical distribution range in the water column, and electivity ranking for seven prey taxa. Rejection of the hypothesis that prey were equally preferred $\left(\mathrm{F}_{\mid 6.20]}=\right.$ 71.9; $K=100 ; W=1.88 ; P<0.001$ ) revealed that the sea lions were not selecting prey species in the environment according to their relative abundances.

The amount of food ingested per feeding period showed values ranging from 0.4 to $57.8 \mathrm{~kg}$ per sea lion. On the average these figures represent $5.7 \%$ of sea lions' body weight (range $=1.9$ to $19.9 \%$ ), a result similar to the values reported for other pinniped species (FAO, 1979; Laws, 1981). Estimates of annual food consumption were ca. $42.5 \times 10^{3}$ tons. When this is calculated for each prey type separately, it indicates that in the study area sea lions consumed ca. 7 times more Genypterus spp. than the 1930 tons annually landed by fishermen.

Table 3. Percent occurrences with respect to predators and meals, numerical and weight contribution and IRI values of prey taxa in the diet of Otaria flavescens

\begin{tabular}{|c|c|c|c|c|c|}
\hline Prey taxon & $\%$ Occ./predators & $\%$ Occ. $/$ meals & $\% \mathrm{~N}^{\circ}$ prey & $\%$ Weight & IRI \\
\hline Macruronus magellanicus & 48.3 & 18.2 & 53.8 & 34.1 & 1 \\
\hline Unidentified Gadiformes & 41.4 & 15.6 & 15.2 & 13.8 & 2.5 \\
\hline Genypterus spp. & 17.2 & 6.6 & 10.4 & 32.2 & 4 \\
\hline Trachurus murphyi & 58.6 & 22.1 & 7.8 & 7.4 & 2.5 \\
\hline Merluccius gayi & 44.8 & 16.9 & 4.9 & 5.8 & 5 \\
\hline Sardinops sagax & 20.7 & 7.8 & 6.6 & 4.8 & 6 \\
\hline Dosidicus gigas & 10.3 & 3.9 & 0.4 & 0.8 & 7 \\
\hline Stromateus stellatus & 10.3 & 3.9 & 0.5 & 0.3 & 8 \\
\hline Unidentified Rajidae & 6.9 & 2.6 & 0.2 & 0.6 & 9 \\
\hline Todarodes spp. & 3.5 & 1.3 & 0.1 & 0.1 & 10.5 \\
\hline Octopus vulgaris & 3.5 & 1.3 & 0.1 & 0.1 & 10.5 \\
\hline $\mathrm{n}$ & 29 & 77 & 820 & $(242 \mathrm{~kg})$ & 11 \\
\hline
\end{tabular}


Table 4. Availability ranking (parentheses, number of occurrences in 74 bottom trawls/total harvest in $\mathrm{kg}$ ), preferred habitat ( $d=$ demersal $_{i} p=$ pelagic), depth range of distribution in the water column (depth of maximum abundance), selectivity ranking (lines couple equally preferred prey) for 7 prey taxa of the South American sea lion Otaria flavescens

\begin{tabular}{|c|c|c|c|c|}
\hline Taxa & Availability & Habitat & Depth (m) & Selectivity \\
\hline Macruronus magellanicus & $6(18 / 250)$ & $\mathrm{D}$ & $\begin{array}{l}0-425 \\
(200)\end{array}$ & 1 \\
\hline Merluccius gayi & $3(46 / 1605)$ & $\mathrm{D}$ & $\begin{array}{l}0-400 \\
(150)\end{array}$ & $\Gamma^{5}$ \\
\hline Trachurus murphyi & $1(\# / \#)$ & $\mathrm{P}$ & $\begin{array}{c}0-250 \\
(75)\end{array}$ & 7 \\
\hline Genypterus spp. & $4(44 / 700)$ & $\mathrm{D}$ & $\begin{array}{c}0-450 \\
(150)\end{array}$ & $L_{4}$ \\
\hline Sardinops sagax & $2(\# / \#)$ & $\mathrm{P}$ & - & $6\rfloor$ \\
\hline Stromateus stellatus & $5(33 / 428)$ & $\mathrm{P}$ & $\begin{array}{c}0-200 \\
(80)\end{array}$ & \rfloor \\
\hline Cephalopods & $7(0 / 0)$ & $D \& P$ & - & 2 \\
\hline
\end{tabular}

\section{DISCUSSION}

The fraction of alimentary tracts that contained food remains is one of the highest recorded in any survey of pinniped food habits. We believe that this is due to the seasonal timing of sampling. Higher feeding activity during the pre-reproductive season has been reported for some pinniped species (Sergeant, 1973) and has also been suggested for Otaria flavescens (Ximénez, 1976). SERPLAC (1981) data support this: of 14 sea lions sampled in the pre-reproductive season, $57 \%$ had food remains, whereas the comparable figure was only $15 \%$ in 33 individuals sampled during the breeding season. In our sample, 2 of the 4 empty tracts belonged to fasting bulls collected during the breeding season and another one to a fasting bull found molting in November 1980. Furthermore, sea lions with the highest weight of food contents were bulls caught in November, i.e. 1 mo before the beginning of the breeding season.

The number of prey individuals per alimentary tract of a sea lion is in part accounted for by the size of the predator, but the time of the day when the sea lion was caught may also be important because in some pinnipeds the amount of food remains decreases as sunset approaches (Spalding, 1964; Street, 1964). The rookeries have the lowest numbers of sea lions at sunrise, which suggests a nocturnal or before-dawn feeding behavior (SERPLAC, 1981). In fact, we caught 22 of the 29 sea lions before midday, however, some of the food remains may not represent simply the food obtained on the most recent feeding period (e.g. the last day). This has been reported for other pinniped species (Frost and Lowry, 1980; Pitcher, 1980). Another bias, the effect of some gorging in part of the sample, may also be affecting our estimation of feeding rates and extrapolated population consumption. We assume that sea lions with scarce food contents counteract that bias.

Stones seem to be voluntarily swallowed by sea lions. They have been frequently found in the stomachs of several pinniped species (Mathisen et al., 1962; Spalding, 1964; Street, 1964) including South American sea lions. Their presence has been interpreted as a means of alleviating the ulcers produced by anisakid nematodes in the stomach fundus as well as of macerating hard parts of their food (Hamilton, 1934; Cattan et al., 1976; but see Spalding, 1964 for other interpretations). However, we observed that in animals with stones, ulcers were frequently located in the lower part of the oesophagus and cardias, where stones cannot crush the nematodes. Because stones are frequent in the stomachs we believe that the presence of 1 loco shell (Concholepas concholepas) previously reported as a food item (Aguayo and Maturana, 1973), should be interpreted better as filling the role of a stone because it seems very unlikely that sea lions prey upon gastropods firmly attached to bottom rocks.

The mean number of prey taxa taken per feeding period is very different among pinniped species for which reports exist. It does not seem to be related to individual size, to diversity of prey resources available, or to the degree of seasonal feeding activity (Taylor et 
al., 1952; Spalding, 1964; Frost and Lowry, 1980; Pitcher, 1980). The assumption that sea lions catch each prey species independently may not hold true, as our results show. It should be taken into consideration that those prey species that live in the vicinity of other preferred prey may become more prone to be caught by the searching predators, as seems to be the case for Macruronus magellanicus and Merluccius gayi. This result implies that not all co-occurring prey taxa represent separate meals. Although in our sample we observed that $80 \%$ of the animals had more than one prey taxon per alimentary tract, we believe that sea lions tend to fill their stomachs with only one prey taxon per feeding period. This conclusion emerges from the observed high degree of dominance of some prey taxa when co-occurring with others. Perhaps the sea lions form a search image according to the preferred and/or the last prey consumed, a contention which is in part supported by their known learning capabilities (Schusterman, 1981). This result could also represent the effect of schooling by the prey, but it is an inappropriate explanation for cusk eels because they do not show this behavior (IFOP, 1979).

The concept implicit in the assessment of 'importance' of a prey taxon in the diet is the possible preference or the degree of selectivity by the predators. However, IRI's generally measure only the relative contribution of each prey taxon, in occurrence, weight, and number of prey individuals to the diet. In some instances, the IRI has been employed as a qualitative measure of resource use by the predators (Pitcher, 1980). This could lead to gross biases, particularly when the contribution of occurrences to the final IRI value is overestimated by considering their frequency over the number of predators in the sample (Pinkas et al., 1971), and the numerical component of the IRI is deleted (Pitcher, 1980). In our sample, Trachurus murphyi had the highest number of occurrences, which probably reflects its position at the top of the availability ranking, but its low dominance, low biomass and numerical contribution accounted for their position at the bottom of the selectivity ranking. We interpret this as meaning that even though sea lions frequently encounter school-forming pelagic fish species (i.e. $T$. murphyi and Sardinops sagax), they have too high escape speeds that render it energetically unrewarding for the sea lions to pursue such small prey. However, these results should be considered a point estimator of the prey selectivity by the sea lions because both availability and selectivity rankings can change seasonally or on a year-to-year basis (Bailey and Ainley, 1982).

Our results indicate that the bulk of the diet of Otaria flavescens is composed of demersal and mesopelagic prey, probably captured over the continental shelf in waters no deeper than $300 \mathrm{~m}$. Three of these prey (Macruronus magellanicus, Merluccius gayi and Genypterus spp.) represent about $75 \%$ by weight of the food found in the alimentary tracts and apart from being larger than sympatric pelagic fishes, they probably are slow swimmers. It should be recalled that among pelagic animals, cephalopods are preferred prey (2nd top position in selectivity ranking); this reinforces previous findings in other pinniped species, for which cephalopods are a frequent and sometimes an important component of their diet (Antonellis and Fiscus, 1980). Opportunistic feeding of sea lions can be envisaged in our results on the basis that, although prey size was not correlated with predator size, the great size similarity among individuals of $\mathrm{M}$. magellanicus within alimentary tracts suggest that sea lions preyed upon schools of similarly aged fish (Fig. 3).

Among the prey reported for the South American sea lion in the Eastern Pacific Ocean, Merluccius gayi, Sebastodes oculatus, Clupea bentinckii and Dosidicus gigas have been more consistently found in samples. However, the high frequency of occurrence of the firstnamed species in SERPLAC's (1981) sample seems to be an overestimation, because otoliths of Macruronus magellanicus appear to have been misidentified (D. Oliva, pers. comm.). Differences in the number of occurrences among samples may in part be explained by the different years, seasons and localities sampled (Aguayo and Maturana, 1973; SERPLAC, 1981). In any case, we believe that the snail Tegula spp. and the spider crab Taliepus dentatus, previously reported as prey, should represent stomach contents of the fishes consumed by sea lions. In this sample the single anchoveta (Engraulis ringens) found was possibly consumed by $M$. gayi, whose otoliths co-occurred in the same stomach where the anchoveta was found.

Our estimates show that sea lions eat about 7 times more cusk eels than are annually landed (SERNAP, 1980,1981 ). In consequence, artisanal fishery and sea lion population may be affecting each other. However, sea lions might be preying upon cusk eel populations that are not currently exploited by the fishery. In fact, artisanal fishermen traditionally fish in very specific areas (IFOP, 1979) for which no estimates of standing stocks exist. While these remain unknown, significant competition of sea lions with man should be considered only as a possibility. Taking into account that the total population size of pinnipeds along the Chilean coast is around 200,000 individuals, it can be estimated that around 500,000 tons of fish are consumed per year by them, which is about $25 \%$ of the current total catch in Chile. It should be considered, however, that the major part of this population inhabits the area southwards of Chiloé Island, where the fishery is at a primitive level, and where South American fur 
seals Arctocephalus australis (Zimmerman) predominate. This is a pinniped whose feeding habits in the Pacific Ocean are unknown.

Acknowledgements. This work was supported by Grant DIUC 98/80 from the Dirección de Investigación, Pontificia Universidad Católica de Chile. F. Benavides, P. Bernal, J. C. Castilla, J. Chong, H. Cortés, M. Gajardo, B. Huet, F. Jaksić, I. Larronde, J. Morillas, P. Ojeda, B. Santelices, L. Vergara and $\mathrm{J}$. Yánez kindly helped in the improvement of this work. Three anonymous reviewers provided valuable suggestions regarding the manuscript.

\section{LITERATURE CITED}

Aguayo, M. (1971). Determinación de la edad en la merluza (Merluccius gayi), Guichenot, 1848, mediante la lectura de otolitos. Bol. Cient. IFOP (6): 1-50

Aguayo, L. A., Maturana, R. (1973). Presencia del lobo marino común (Otaria flavescens) en el litoral chileno. Bio. Pesq. Chile (6) : 45-75

Anderson, K. P., Ursin, E. (1977). A multispecies extension to the Beverton and Holt theory of fishing, with accounts of phosphorous circulation and primary production. Meddr Danm. Fisk.-og Havunders. 7: 319-435

Antonellis, G. A., Fiscus, C. H. (1980). The pinnipeds of the California Current. CALCOFI Rep. Vol. XXI: $68-75$

Bailey, K. M., Ainley, D. G. (1982). The dynamics of California sea lion predation on Pacific hake. Fish. Res. 1: 163-176

Boswall, J. (1972). South American sea lion Otaria byronia as a predator on penguins. Bull. Mus. Ornithol. Club. 95 (5): $124-132$

Carrara, I. S. (1952). Lobos marinos, pingüinos y guaneras de las costas del litoral marítimo e islas adyacentes de la República de la Argentina (1). Min. Educ. Nac. de la Plata. Fac. Cs. Vet. (Pub. especial). Ene. 1952

Cattan, P. E., Babero, B. B., Torres, D. (1976). The helminth fauna of Chile: IV Nematodes of the genera Anisakis Dujardin, 1845 and Phocanema Myers, 1959 in relation with gastric ulcers in a South American sea lion Otaria byronia. J. Wildl. Dis. 12: 511-515

Clarke, M. R. (1962). The identification of cephalopod 'beaks' and the relationship between beak size and total body weight. Bull. Br. Mus. Nat. Hist. 8 (10): 419-480

Estes, J. A. (1979). Exploitation of marine mammals: r-selection of k-strategists? J. Fish. Res. Bd Can. 36: 1009-1017

Fager, E. W. (1957). Determination and analysis of recurrent groups. Ecology 38: 586-595

FAO (1978). Mammals in the seas, Vol. I. FAO Fish. Series $5(1): 1-264$

FAO (1979). Mammals in the seas, Vol. II. FAO Fish. Series $5(2): 1-151$

Fiscus, C. H. (1979). Interactions of marine mammals and Pacific hake. Mar. Fish. Rev. 4 (10): 1-9

Fiscus, C. H. (1982). Predation by marine mammals on squids of the Eastern North Pacific Ocean and the Bering Sea. Mar. Fish. Rev. 44 (2): 1-10

Frost, K. S., Lowry, L. I. (1980). Feeding habits of Ribbon seals (Phoca fasciata) in the Bering Sea in spring. Can. J. Zool. 58: 1601-1607

George-Nascimento, M., Carvajal, J. (1981). Helmintos parásitos del lobo marino común Otaria flavescens en el golfo de Arauco, Chile. Bol. Chile. Parasit. 36: 72-73

Hamilton, J. E. (1934). The South American sea lion, Otaria byronia (Blainville). 'Discovery' Rep. 1 (VIII): 269-318
Hayes, W. B. (1978). Some sampling properties of the Fager index for recurrent species groups. Ecology 59 (1): $194-196$

Hecht, T. (1978). A descriptive systematic study of the otoliths of the Neopterygean marine fishes of South Africa. Part I. Introduction. Trans. R. Soc. S. Afr. 43 (2): 1-4

Hecht, T., Hecht, A. (1978). Delimitation of teleost orders, some systematic notes and provisional new phyletic order sequence. Trans. R. Soc. S. Afr. 43 (2): 4-26

Henríquez, J. (1982). Cuantificación de recursos demersales por medio del método de area barrida en la zona comprendida entre Isla Gủafo $\left(43^{\circ} 23^{\prime}\right.$ L.S.) y la desembocadura del río Itata $\left(36^{\circ} 27^{\prime} 60\right.$ L.S.) en el periodo primavera del año 1981. Inf. práctica profesional Técnico Marino, P. Universidad Católica de Chile, p. 1-21

IFOP (1979). Estado actual de las principales pesquerías nacionales. Bases para un desarrollo pesquero, Vol. I. Peces, CORFO, Santiago

Johnson, D. H. (1980). The comparison of usage and availability measurements for evaluating resource preference. Ecology 61 (1): 65-71

Laws, R. M. (1981). Biology of antarctic seals. Sci. Prog., Oxford 67: 377-397

Lehmann, E. L. (1975). Nonparametrics: statistical methods based on ranks. Holden-Day, San Francisco, California, USA

Majkowski, J. (1981). Application of a multispecies approach for assessing the population abundance and age structure of fish stocks. Can. J. Fish. Aquat. Sci. 38: 424-431

Mathisen, O. E., Baade, R. T., Lopp, R. J. (1962). Breeding habits, growth and stomach contents of the Steller sea lion in Alaska. J. Mammal. 43 (4): 469-477

May, R. M., Beddington, J. R., Clark, C. W., Holt, S. J., Laws, R. M. (1979). Management of multispecies fisheries. Science, N.Y. 205 (4403): 267-276

Parrish, B. B., Shearer, W. M. (1977). Effects of seals on fisheries. ICES CM 1977/M: 14, Anancat. Comm.

Pinkas, L., Oliphant, M., Iverson, I. (1971). Food habits of albacore, blue fin tuna and bonito in California waters. Calif. Dep. Fish \& Game, Fish. Bull. 152: 1-105

Pitcher, K. W. (1980). Stomach contents and feces as indicators of harbor seal, Phoca vitulina, foods in the Gulf of Alaska. Fish. Bull. U.S. 78: 797-798

Saavedra, R. V. (1980). Isla Metalqui, una lobería que necesita protección. Medio Ambiente 4 (2): 35-41

Schlatter, R. P. (1977). Penetración del lobo marino común, Otaria flavescens Shaw, en el río Valdivia y afluentes. Medio Ambiente 2 (1): 86-90

Schusterman, R. J. (1981). Behavioral capabilities of seals and sea lions: a review of their hearing, visual, learning and diving skills. Psychol. Rec. 31: 125-143

Sergeant. D. E. (1973). Feeding, growth, and productivity of Northwest Atlantic harp seals (Pagophilus groenlandicus). J. Fish. Res. Bd Can. 30 (1): 17-29

Sergeant, D. E. (1976). History and present status of populations of harp and hooded seals. Biol. Conserv. 10: 95-118

SERNAP (1980). Anuario estadístico de pesca. Ministerio de Economia, Fomento y Reconstrucción, Chile

SERNAP (1981). Anuario estadístico de pesca. Ministerio de Economía, Fomento y Reconstrucción, Chile

SERPLAC (1981). Estudio del aprovechamiento del lobo marino en la VII Región, Chile. Informe de avance de la II y III etapas Intendencia Region del Maule, Talca, Chile

Sielfeld, W., Venegas, C., Atalah, A. (1977). Consideraciones acerca del estado de los mamíferos marinos de Chile. An. Inst. Pat. 8: 297-315

Sielfeld, W., Venegas, C., Atalah, A., Torres, J. (1978). Pros- 
pección de otáridos en las costas de Magallanes. Ans. Ins. Pat. 9: 157-171

Spalding, D. J. (1964). Comparative feeding habits of the fur seal, sea lion, and harbor seal on the British Columbia coast. Bull. J. Fish. Res. Bd Can. 146: 1-52

Street, R. J. (1964). Feeding habits of the New Zealand fur seal Arctocephalus forsteri. New Zealand Marine Department Fisheries Technical Report No 9. 20 pp.

Taylor, F. H. C., Fujinaga, M., Wilke, F. (1952). Distribution and food habits of the fur seals of the North Pacific Ocean. U.S. Fish Wildl. Serv. $N^{\circ} 10: 1-86$
Vaz-Ferreira, R. (1979). South American sea lion. Report of the advisory committee on Marine resources research working party on marine mammals. Pinnipeds species. Summaries, La Jolla, USA 1979: 21-25

Ximénez, I. (1976). Dinámica de la población de O. flavescens (Shaw), en el área Península Valdez y zonas adyacentes. Prov. de Chubut, Rep. Argentina. Centro Nac. Patagónico, Inf. Tec. 1.4.1.: 1-52

This paper was presented by Dr. J. E. Winter; it was accepted for printing on August 26, 1984 